Кудлаев Д. В., Тищенко А. В. Неэффективность децентрализации государственной собственности в сфере лесопользования в Приморье: причины и возможные последствия

Азиатско-Тихоокеанский регион: экономика, политика, право. 2021. Т. 24, № 4. С. $29-51$. Pacific Rim: Economics, Politics, Law. 2021. V. 24, No 4. P. 29-51.

\title{
ЭКОНОМИКА
}

Научная статья

УДК 630.92(571.63)

https://doi.org/10.24866/1813-3274/2021-4/29-51

\section{НЕЭФФЕКТИВНОСТЬ ДЕЦЕНТРАЛИЗАЦИИ ГОСУДАРСТВЕННОЙ СОБСТВЕННОСТИ В СФЕРЕ ЛЕСОПОЛЬЗОВАНИЯ В ПРИМОРЬЕ: ПРИЧИНЫ И ВОЗМОЖНЫЕ ПОСЛЕДСТВИЯ}

\author{
Дмитрий Вячеславович Кудлаев ${ }^{1}$, Андрей Владимирович Тищенко ${ }^{2}$ \\ ${ }^{1,2}$ Школа экономики и менеджмента, Дальневосточный федеральный \\ университет, 690922, Россия, Владивосток, о. Русский, п. Аякс, 10, ауд. 320 G \\ ${ }^{1}$ kudlaev.dv@dvfu.ru, https://orcid.org/0000-0002-7989-112X \\ 2 tishchenko.av@dvfu.ru, https://orcid.org/0000-0002-4162-355X
}

Аннотащия. Во введении описана проблема неэффективной децентрализации государственной собственности как ключевой фактор системного кризиса лесного хозяйства в Приморском крае. В рамках теоретической части статьи рассматриваются научные труды, посвящённые классификации прав собственности на натуральные ресурсы и политике децентрализации государственной собственности в сфере лесопользования в разных странах мира, а также анализируется ситуация в лесопользовательских отношениях между субъектами на территории Приморского края. Разработана вербальная модель децентрализации в Приморском крае. Приведены барьеры, мешающие развитию лесохозяйственной отрасли в регионе и влияющие на результативность данной политики. В эмпирической части исследовательской работы приводятся примеры практических кейсов из коррупционных дел, обстоятельств превышения должностных полномочий, а также примеры случаев некомпетентности представителей государственных органов в лесной отрасли. Завершая статью, авторы на основе описанного материала приводят доказательства неэффективности децентрализации в Приморье, ведущей к истощению лесных ресурсов, снижению доходных статей бюджета края и к общему ухудшению условий проживания в регионе.

(C) Кудлаев Д. В., Тищенко А. В., 2021 
Ключевые слова: государственная собственность, децентрализация государственной собственности, децентрализация управления, муниципальное управление, делегирование полномочий, права собственности, институциональные изменения, институциональная структура, лесопользование, лесная отрасль, проблемы лесной отрасли, Лесной кодекс РФ, лесные ресурсы, управление лесным хозяйством, воспроизводство ресурсов, теневая экономика, коррупция, злоупотребление должностными полномочиями, Дальний Восток, Приморский край.

Для цитирования: Кудлаев Д. В., Тищенко А. В. Неэффективность децентрализации государственной собственности в сфере лесопользования в Приморье: причины и возможные последствия // Азиатско-Тихоокеанский регион: экономика, политика, право. 2021. № 4. С. 29-51. https://doi.org/10.24866/1813-3274/2021-4/29-51.

\title{
ECONOMICS
}

Original article

\section{INEFFECTIVE DECENTRALIZATION OF STATE PROPERTY IN THE FORESTRY OF PRIMORSKY KRAI: CAUSES AND POSSIBLE CONSEQUENCES}

\author{
Dmitry V. Kudlaev ${ }^{1}$, Andrey V. Tishchenko ${ }^{2}$ \\ ${ }^{1,2}$ School of Economics and Management, Far Eastern Federal University, 690922, \\ Russia,Vladivostok, Russkiy Island, p. Ajax, 10, room 320 G \\ ${ }^{1}$ kudlaev.dv@dvfu.ru, https://orcid.org/0000-0002-7989-112X \\ 2 tishchenko.av@dvfu.ru, https://orcid.org/0000-0002-4162-355X
}

Abstract. The introduction describes the problem of ineffective decentralization of state property as a key factor in the systemic crisis of forestry in Primorsky Krai. The theoretical part of the article is devoted to the analysis of research works on the classification of property rights for natural resources and the policy of decentralization in different countries of the world; the situation in forest management relations between entities on the territory of Primorsky Krai is also reviewed. A verbal model of decentralization in Primorsky Krai has been developed, possible barriers hindering the development of the forestry industry in the region and affecting the efficiency of this policy are presented. The empirical part of the research work provides practical examples of corruption cases, circumstances of abuse of office, as well as examples of cases of incompetence of state bodies in the forestry sector. In conclusion, the authors, based on the described material, provide evidence of the ineffectiveness of decentralization in Primorye that leads to the 
Кудлаев Д. В., Тищенко А. В. Неэффективность децентрализации государственной собственности в сфере лесопользования в Приморье: причины и возможные последствия

depletion of forest resources, a decrease in revenue items of the regional budget and a general deterioration in living conditions in the region.

Keywords: state ownership, decentralization of state ownership, decentralization of management, municipal management, delegation of powers, property rights, institutional changes, institutional structure, forestry, forest industry, forestry problems, Forest Code of the Russian Federation, forest resources, forestry management, resource reproduction, shadow economy, corruption, abuse of office, Far East, Primorsky Krai.

For citing: Kudlaev D. V., Tishchenko A. V. Ineffective decentralization of state property in the forestry of Primorsky Krai: causes and possible consequences // PACIFIC RIM: Economics, Politics, Law. 2021. No. 4. P. 29-51. https://doi.org/10.24866/1813$3274 / 2021-4 / 29-51$.

\section{Введение}

Лесное хозяйство на протяжении многих десятилетий является важнейшим элементом экономики Приморья. Охота, сельское и лесное хозяйство вместе с обрабатывающей промышленностью занимают третье место в отраслевой структуре региона, и за восемь лет, в период с 2009 г. по 2017 г., отношение объёмов данных отраслей к общему объёму ВРП Приморского края выросло с 12\% до 20\% [1]. Несмотря на это, многие жители Дальнего Востока, общественные активисты и исследователи заявляют о неэффективном использовании лесного ресурса. Несколько десятилетий подряд на Дальнем Востоке скорость расширения объёмов вырубленных или изменённых лесных земель превышает темп роста производственных мощностей, что свидетельствует о негативной тенденции экстенсивного освоения, которая может привести к системному кризису лесопромышленного комплекса региона. Так, А. Шейнгауз свидетельствует о том, что лесное хозяйство Дальнего Востока находится в углубляющемся кризисе, начиная со времен перестройки и последовавших реформ и реорганизаций. В итоге объёмы производства и добычи леса сократились в несколько раз за период с 1988 г. по 2003 г. Кроме этого, правовые и институциональные изменения в России привели к дестабилизации и неопределённости в лесной отрасли, что сказывается не только на эффективности использовании лесного ресурca, но и на качестве жизни будущих поколений [2, с. 45; c. 53-54, 65].

На сегодняшний день в Приморье действует политика децентрализации: между центральной властью и властью субъекта есть разграничение прав собственности на лесные ресурсы, региональные власти могут также передавать права собственности на лес другим участникам лесохозяйственных отношений: физическим лицам, предпринимателям и компаниям. Это произошло в результате реформ прав собственности после распада Советского Союза и в начале 2000-х гг. Исследования Института экономических исследований ДВО РАН показывают, что изменения в 
правах собственности привели к тому, что лесное хозяйство и лесопромышленный комплекс - основополагающие подсистемы лесного комплекса - стали базироваться на различных формах собственности: лесное хозяйство - на государственной, лесопромышленное производство - на частной [3]. Важным институциональным фактором стало изменение условий получения лесосырьевых участков в пользование: в советское время лесные участки доставались предприятиям практически бесплатно, тогда как сейчас, под влиянием рыночных отношений, лесопользование стало платным и срочным. Н. Е. Антонова анализирует механизмы, пропорции и динамику функционирования лесного комплекса Дальнего Востока, которые претерпели существенные изменения и привели к возникновению таких проблем, как высокая доля неформальных отношений в лесном комплексе, сокращение разнообразия лесопромышленных предприятий, экспортоориентированный и криминализированный характер отрасли.

Практические примеры, приведённые в основной части данной статьи, ярко иллюстрируют неэффективность метода децентрализации. Возникает вопрос: почему, несмотря на теоретически сформулированные преимущества политики децентрализации государственной собственности на лесные ресурсы, данная методика в Приморском крае работает плохо? Гипотеза исследования заключается в том, что децентрализация прав собственности на лесные ресурсы в России работает неэффективно и противоречит тем преимуществам, которые должны наблюдаться согласно ключевым положениям теории прав собственности в рамках новой институциональной теории. Целью представленной работы является выяснение того, какие факторы мешают гармоничному развитию лесной инфраструктуры и эффективному управлению лесными ресурсами посредством децентрализации государственной собственности, на примере Приморского края.

Данное исследование актуально, так как лесопромышленная отрасль является важной частью социально-экономических процессов в Приморском крае. Нерешённость проблем, которые существуют в системе лесохозяйственных отношений, и экстенсивное использование лесов ведут к их истощению. Слабый надзор и низкий уровень ухода за лесом уже в ближайшей перспективе могут стать причиной не только снижения доходных статей бюджета края, но и утраты лесами экологической ценности.

\section{Теоретические аспекты прав собственности на натуральные ресурсы. Мировой опыт децентрализации}

Рассматривая концепцию прав собственности на натуральные ресурсы, E. Schlager, E. Ostrom (1992) исследуют права собственности на примере водных ресурсов различных стран. «Право собственности - это право предпринимать определённые действия, относящиеся к определённой области» [4, с. 250]. Авторы считают «права» и «правила» взаимосвязанными понятиями, если это касается при- 
Кудлаев Д. В., Тищенко А. В. Неэффективность децентрализации государственной собственности в сфере лесопользования в Приморье: причины и возможные последствия

родных ресурсов. Права - это разрешённые действия, которые может осуществлять субъект, а правила - предписания, создающие авторизацию. Для каждого права существуют определённые правила, разрешающие или требующие определённых действий при реализации права собственности. Какие же права есть у ресурсов общего пула? Проанализировав указанную выше статью, мы составили классификационную таблицу прав собственности (табл. 1).

Таблица 1

\section{Классификация прав собственности на натуральные ресурсы}

Classification of property rights for natural resources

\begin{tabular}{|c|c|c|c|c|}
\hline Право доступа & $\begin{array}{c}\text { Право } \\
\text { на изъятие }\end{array}$ & $\begin{array}{c}\text { Право } \\
\text { на управление }\end{array}$ & $\begin{array}{c}\text { Право } \\
\text { исключения }\end{array}$ & $\begin{array}{c}\text { Право } \\
\text { на отчуждение }\end{array}$ \\
\hline $\begin{array}{l}\text { Право доступа } \\
\text { к определён- } \\
\text { ной реальной } \\
\text { собственности, } \\
\text { непотреби- } \\
\text { тельского ис- } \\
\text { пользования } \\
\text { собственности }\end{array}$ & $\begin{array}{l}\text { Право извлече- } \\
\text { ния выгоды из } \\
\text { ресурса, про- } \\
\text { дуктивного } \\
\text { использования } \\
\text { собственности } \\
\text { для получения } \\
\text { прибыли }\end{array}$ & $\begin{array}{l}\text { Право регули- } \\
\text { ровать внут- } \\
\text { реннюю модель } \\
\text { потребления и } \\
\text { осваивать ре- } \\
\text { сурс путём вне- } \\
\text { сения улучше- } \\
\text { ний, устанав- } \\
\text { ливать и изме- } \\
\text { нять правила } \\
\text { использования } \\
\text { собственности }\end{array}$ & $\begin{array}{l}\text { Право опреде- } \\
\text { лять, у кого } \\
\text { будет право } \\
\text { доступа, ис- } \\
\text { ключать неко- } \\
\text { торых пользо- } \\
\text { вателей и уста- } \\
\text { навливать пра- } \\
\text { вила доступа к } \\
\text { собственности }\end{array}$ & $\begin{array}{l}\text { Право прода- } \\
\text { вать, сдавать } \\
\text { в аренду и } \\
\text { наследовать } \\
\text { имущество }\end{array}$ \\
\hline
\end{tabular}

Источник: составлена авторами на основе [4]. Source: compiled by the authors based on [4]

Eric A. Coleman, Scott S. Liebertz приписывают наибольшую ограниченность праву доступа. Например, если рассматривается лес, то права доступа указывают на то, что пользователь может войти в лес, но не имеет права использовать ресурсы, то есть рубить дрова. Право изъятия позволяют лесопользователю как входить в лес, так и извлекать лесную продукцию для получения прибыли, личного использования. Также авторы отмечают некую двойственность в праве управления: «Некоторые пользователи могут участвовать в управлении лесами, а другие также могут принимать общие управленческие решения» [5, с. 650]. Лица, обладающие правами управления, имеют право определять, как, когда и где может происходить сбор ресурсов, а также возможность и способы изменения структуры ресурса. Пользователь с правами исключения может определить, кто входит в лес, извлекает из него древесину или управляет им. Наконец, право отчуждения позволяет его обладателю передать часть прав или все права другому субъекту или группе, сдавать ресурс в 
аренду или продавать его. Таким образом, объём прав определяет тот объём решений, который может принять правообладатель.

Очевидно, что пользователи ресурсов общего пула реализуют свои права собственности, чтобы получить выгоду от ресурсов, будь то прибыль от продажи вырубленных деревьев или от сдачи в аренду лесного участка. Из этого следует, что те, у кого нет прав собственности, выгоду от ресурса не получат напрямую. Пользователи с ограниченными правами могут использовать ресурс, однако устанавливать ограничивающие правила не могут. Лица с широкими правами собственности имеют прямой доступ к ресурсным благам и могут ограничивать выгоды других. Основываясь на этих утверждениях, можно согласиться с гипотезой о том, что обширные права собственности пользователей положительно коррелируют с преимуществами ресурсов общего пула: «..обладание обширными правами с большей вероятностью принесёт экономические, экологические и культурные, духовные преимущества, ценимые пользователем с более широкими правами собственности» [5, с. 652].

Решающим правом для эффективного использования ресурсов является право отчуждения. Оно в сочетании с правами исключения «создаёт у владельцев стимулы для осуществления долгосрочных инвестиций в ресурс» [4, с. 256]. Долгосрочные выгоды от инвестиций заключаются в будущей продаже или аренде всех или части принадлежащих владельцам прав собственности. Также отчуждение позволяет переключить ресурс с менее продуктивного на более продуктивное использование, однако возможен риск чрезмерной эксплуатации ресурса и его уничтожения. Право исключения тоже создает сильные стимулы для владельцев и собственников делать текущие инвестиции в ресурсы, потому что собственники и владельцы могут решать, кто может и не может входить в ресурс, они могут извлекать выгоду от вносимых инвестиций. Невозможно не учитывать желание и способность различных пользователей влиять на соблюдение правил. Одни только формальные права собственности не гарантируют, что пользователь получит выгоду от ресурсов. Права собственности на природные ресурсы неизбежно вступают в конфликт, поскольку пользователи конкурируют за исчерпаемый ресурс, добиться успешного соблюдения правил довольно сложно. Если влиятельные пользователи получают больше выгод, прибегая к злоупотреблению своими обширными правами, то права собственности усилят существующее этническое и экономическое неравенство. Однако сильные пользователи могут эффективно или неэффективно контролировать исполнение местных правил, поэтому осуществление такого мониторинга в России является довольно проблемным, несмотря на то, что государство тратит огромные средства на выявление нарушений в лесной сфере (аэрокосмический мониторинг, рейды по отлову браконьеров в лесу, различные системы учёта происхождения и движения древесины). 
Кудлаев Д. В., Тищенко А. В. Неэффективность децентрализации государственной собственности в сфере лесопользования в Приморье: причины и возможные последствия

Eric A. Coleman, Scott S. Liebertz исследовали феномен децентрализации в Боливии, Кении, Мексике и Уганде, которые ввели у себя данную политику для лесных ресурсов. Они считают, что последствия государственной политики, такой как децентрализация, которая коренным образом меняет права собственности в государстве, ещё полностью не изучены. Благодаря эмпирическим данным, полученным в результате построения эконометрических моделей, интервью, выяснилось, что домохозяйства с обширными имущественными правами получают больше льгот по ресурсам общего пула, чем домохозяйства с ограниченными правами собственности. В частности, чем шире права собственности у домохозяйства, тем больше вероятность того, что домохозяйство укажет, что лес предоставляет им различные экологические, экономические и культурные преимущества. Для того, чтобы пользователи ресурсов могли осуществлять деятельность с наибольшими выгодами от ресурсов, они должны иметь возможность участвовать во всеобъемлющем управлении общими ресурсами через более широкие права собственности, а именно участвовать в принятии управленческих решений в отношении леса. Авторы в целом положительно отзываются о политике децентрализации.

A. Larson, A. Pacheco, F. Toni в своей работе под децентрализацией понимают передачу полномочий от центрального правительства к более низким уровням в политико-административной и территориальной иерархии. Но это неполное определение, без учёта доступа к лесным ресурсам для местных жителей и необходимости сохранения леса, поэтому в исследовании авторы принимают за основную цель децентрализации то, что она должна улучшать условия жизни бедных слоев населения, зависящих от леса, при одновременном сохранении лесных товаров и услуг. Авторы считают, что, несмотря на теоретически аргументированные преимущества, децентрализация в лесном хозяйстве на практике может иметь пагубные последствия для людей, зависящих от лесов. Чтобы лучше понять влияние децентрализации на доступ к активам средств к существованию, результаты тематического исследования интерпретируются этими авторами с использованием предложенной модели взаимодействия, основанной на модифицированной структуре устойчивого жизнеобеспечения. Результаты их исследования показывают, что доступ к естественному капиталу можно сделать более уязвимым за счёт децентрализации, если она не идёт рука об руку с мерами по устранению структурного неравенства, такими как права на землю [6]. В то же время децентрализация может усилить политические аспекты социального капитала (например, доступ к принятию решений). Тем не менее, это зависит от расширяющегося участия и нисходящей подотчётности, а также от полномочий местных властей. Кроме того, необходимые изменения редко происходят без конкретных организованных требований местных ассоциаций и движений. Об институциональных барьерах в лесохозяйственной отрасли говорит и К. Andersson [7, с. 6]. 
Исследуя децентрализацию в Боливии, A. Larson, A. Pacheco, F. Toni определяют децентрализацию как набор институциональных механизмов между государственными учреждениями и социальными субъектами, которые возникают из более широкого процесса с двумя основными измерениями [6, с. 253]:

1. Нисходящие меры, направленные на передачу ответственности - политической, административной и / или финансовой - на более низкие уровни правительства.

2. Постепенное открытие пространства для участия снизу, вызванное действиями социальных движений и местных органов власти, которые бросают вызов традиционному (централизованному) способу принятия решений государственной политики.

Авторы разделяют эффекты от управления муниципалитетов по видам капитала [6, с. 261]:

1. По природному капиталу местному населению требуется облегченный бюрократический доступ к лесным ресурсам, но возможно, что и муниципалитеты будут более склонны к тому, чтобы облегчать бюрократический доступ лесозаготовительным компаниям, а местному населению, наоборот, - усложнять.

2. По экономическому капиталу местному населению нужны дешёвые кредиты, с другой стороны, муниципалитеты могут усложнять процедуру получения ссуды, а также облагать дополнительными налогами и применять штрафы.

3. По физическому капиталу коренные жители нуждаются в хорошей инфраструктуре и технологиях для пользования лесными ресурсами, но муниципалитеты могут предоставлять это только коммерческим компаниям.

4. По человеческому капиталу от муниципалитетов ждут, что они будут предоставлять информацию, необходимую для добычи лесных ресурсов, но также они могут быть склонны к предоставлению информации и склонению законов в пользу элиты.

5. По социальному капиталу местное население ожидает, что со стороны властей будет поддержка местных сообществ, с другой стороны, в муниципалитетах такой поддержки может и не быть, более того в них может состоять элита, преследующая собственные цели.

Исходя из исследованных теоретических материалов, можем сказать, что политика децентрализации в сфере лесопользования облегчает получение прав на пользование лесными ресурсами для местного населения, благодаря тесному контакту с местным населением муниципалитеты принимают во внимание требования и просьбы местных групп, например, такие, как развитие местной инфраструктуры, финансовая помощь. Проведя анализ статей и другой собранной информации, мы можем перечислить факторы, при которых децентрализация будет работать так, как предполагалось; они подразделяются на внешние и внутренние факторы.

К внешним факторам относят:

1. Значительную передачу полномочий и прав подотчётному муниципалитету. 
Кудлаев Д. В., Тищенко А. В. Неэффективность децентрализации государственной собственности в сфере лесопользования в Приморье: причины и возможные последствия

2. Понятные права собственности, подкреплённые законами, а также соблюдение этих законов государством, частными компаниями и гражданами.

3. Эффективная связь между государством, гражданами и частными компаниями.

К внутренним факторам можно отнести:

1. Эффективное и сбалансированное распределение полномочий и ответственности в государственных структурах.

2. Ресурсы и институциональная поддержка в этих структурах.

3. Плотное сотрудничество этих структур с гражданами и частными компаниями.

Примером страны, которая успешно смогла применить политику децентрализации в сфере лесного хозяйства, является Боливия, где местные органы самоуправления в основном исполняли обязанности, связанные с мониторингом и обеспечением соблюдения формальных правил. Муниципальные органы власти несут ответственность за определение и разграничение государственных лесных угодий на муниципальной территории, которые должны использоваться исключительно для местных сообществ. «Более того, муниципалитеты наделены правом использовать собственные стратегии для удовлетворения потребностей лесопользователей в их юрисдикции, если стратегия не противоречит официальному режиму» [7, с. 9]. Но даже при хорошем финансировании и предоставленных правах муниципалитетам пришлось столкнуться с серьёзными институциональными стимулами, после чего и появилась необходимая мотивация для решения проблем.

В Канаде в 90-х годах с подачи провинций было предложено создание Канадского лесного соглашения, ввиду которого 94\% всего леса является общественным достоянием. Это послужило тому, что теперь многие провинции имеют законы, требующие участия общества в лесном управлении, что не допускает незаконную добычу лесных ресурсов [8, p. 79]. Можно сделать вывод о том, что грамотная децентрализация прав собственности представляет собой значительную передачу полномочий и обязанностей нижним уровням государственного управления, что позволяет эффективно и сбалансированно распределять ответственность и полномочия между различными субъектами лесохозяйственных отношений. В процессе децентрализации наблюдаются ясность прав собственности на лесные ресурсы, верховенство закона, рациональное использование лесных ресурсов, преследуется долгосрочная перспектива использования ресурсов.

\section{Трансформация прав собственности на лесные ресурсы в РФ и Приморском крае}

Если проанализировать изменение прав на собственность лесных ресурсов в Российской Федерации, то можно увидеть множество преобразований в Лесном кодексе РФ и во взаимоотношениях федерального центра и субъектов страны. По данным Продовольственной и сельскохозяйственной организации Объединенных Наций, в России 
преобладает публичная форма собственности на лесные ресурсы [9]. Они принадлежат государству или административным единицам государственного управления или учреждениям, или корпорациям, принадлежащим к государственному управлению. Общая площадь лесных ресурсов в Приморском крае - 13 370,4 тыс. га, из них защитные леса составляют 4 610,2 тыс. га, эксплуатационные - 8 760,2 тыс. га. Покрытые лесной растительностью земли составляют 12 824,8 тыс. га. Лесистость края составляет 79,3 \% (с колебаниями от 92 \% в северных районах - до 6 \% в юго-западных). В соответствии с Лесным кодексом РФ органы государственной власти Российской Федерации имеют все права, описанные в табл. 1. Администрации Приморского края переданы права на доступ, изъятие, исключение и отчуждение [10]. Распоряжение лесными участками, государственная собственность на которые не разграничена, осуществляется органами исполнительной власти субъектов Российской Федерации, органами местного самоуправления в соответствии с земельным законодательством. Непосредственно полномочия субъекта реализуются управлением лесного хозяйства Приморского края.

Таблицуа 2

\section{Классификация держателей права управления публичными лесами}

\section{Classification of holders of public forest management rights}

\begin{tabular}{|l|l|}
\hline \multicolumn{1}{|c|}{ Категория пользователя } & \multicolumn{1}{c|}{ Определение } \\
\hline Гпсударственное & $\begin{array}{l}\text { Государственная администрация (или учреждения или кор- } \\
\text { порации, принадлежащие государственной администрации) } \\
\text { сохраняет права и обязанности управления в пределах, } \\
\text { установленных законодательством. }\end{array}$ \\
\hline Физические лица & $\begin{array}{l}\text { Права и обязанности по управлению лесным хозяйством } \\
\text { передаются от государственной администрации к частным } \\
\text { лицам или домохозяйствам по долгосрочным договорам } \\
\text { аренды или управления }\end{array}$ \\
\hline $\begin{array}{l}\text { Субъекты и учреждения } \\
\text { частного бизнеса }\end{array}$ & $\begin{array}{l}\text { Права и обязанности по управлению лесным хозяйством } \\
\text { передаются от государственной администрации корпора- } \\
\text { циям, частным кооперативам, частным некоммерческим } \\
\text { организациям и ассоциациям и т. д. Другим хозяйствую- } \\
\text { щим субъектам - на основе долгосрочной аренды или со- } \\
\text { глашений об управлении. }\end{array}$ \\
\hline $\begin{array}{l}\text { Местные, племенные } \\
\text { и коренные общины }\end{array}$ & $\begin{array}{l}\text { Права и обязанности по управлению лесами передаются от } \\
\text { государственной администрации местным общинам (вклю- } \\
\text { чая коренные и племенные общины) на основе долгосроч- } \\
\text { ной аренды или соглашений об управлении. }\end{array}$ \\
\hline Неизвестно / другое & $\begin{array}{l}\text { Леса, передача прав управления которыми не относится ни } \\
\text { к одной из упомянутых выше категорий. }\end{array}$ \\
\hline
\end{tabular}

Источник: [9]. Source: [9] 
Кудлаев Д. В., Тищенко А. В. Неэффективность децентрализации государственной собственности в сфере лесопользования в Приморье: причины и возможные последствия

Кроме этого, исходя из данных Продовольственной и сельскохозяйственной организации Объединенных Наций, в Российской Федерации преобладает способ передачи лесных ресурсов с помощью долгосрочной аренды (табл. 2). Получается, что Лесной Кодекс РФ определяет все леса как государственную собственность, «которую могут использовать физические и юридические лица только на правах пользования» [11, с. 64]. Лесной фонд, находящийся в ведении управления лесным хозяйством Приморского края, по состоянию на 01.01.2010 г. составляет 11 955,3 тыс. га, из них покрыты лесной растительностью 11 477,8 тыс. га (96\%) [12]. На площадях, переданных в аренду (56 \% площадей лесного фонда края), выполнение работ по охране, защите и воспроизводству лесов возложено на арендаторов лесного фонда. Управление лесным хозяйством осуществляет контроль за деятельностью арендаторов. На свободных от закрепления землях лесного фонда лесохозяйственные мероприятия осуществляются на основе государственных контрактов, заключаемых управлением лесным хозяйством на основании торгов.

На сайте torgi.gov.ru реализуются два вида предоставления прав на лесные ресурсы. Первое - продажа лесных насаждений под вырубку, без фактических прав собственности (только право доступа, право на изъятие), второе - сдача лесного участка в долгосрочную аренду с ограниченными видами деятельности на них, например, заготовка древесины, осуществление видов деятельности в сфере охотничьего хозяйства, создание лесных плантаций и их эксплуатация, выращивание лесных, плодовых, ягодных, декоративных растений, лекарственных растений, осуществление геологического изучения недр, разведка и добыча полезных ископаемых, переработка древесины и иных лесных ресурсов. Следовательно, в этом случае частично осуществляется право доступа (арендатор не вправе препятствовать доступу граждан на арендованный лесной участок, а также осуществлению заготовки и сбору находящихся на них пищевых и недревесных лесных ресурсов (статья 3.5 Лесного кодекса РФ), а также право изьятия [13]. Интересно заметить, что в таком варианте предоставления собственности реализуется право на сервитут, то есть частичное право отчуждения, но только с согласия арендодателя. Российская Федерация может также передавать органам государственной власти субъектов Российской Федерации осуществление полномочий по предоставлению лесных участков, расположенных в границах земель лесного фонда, в постоянное пользование, аренду, безвозмездное пользование, по заключению договоров куплипродажи лесных насаждений, расположенных на землях лесного фонда, подготовке, организации и проведению торгов на право заключения договоров аренды лесных участков, находящихся в государственной или муниципальной собственности, аукционов на право заключения договоров купли-продажи лесных насаждений, установлению сервитутов в отношении лесных участков, расположенных в границах земель лесного фонда. 
Действительно, Россия проделала большой путь к децентрализации и разделению прав собственности между центром и регионами. С реформой Лесного Кодекса и федеративным управлением государственная власть передала некоторые права собственности субъектам, которые можно классифицировать согласно табл. 1., а именно право доступа, право изъятия, право исключения и отчуждения; правом управления субъекты не обладают. Дальше власти регионов могут наделять ограниченными правами собственности на лесные ресурсы физических лиц, частных предпринимателей и юридических лиц (право доступа, право изъятия). Однако эффективна ли такая политика с точки зрения рационального использования ресурсов и экологии в целом? Несмотря на все изложенные в теории преимущества децентрализации и успешный опыт развитых стран, картина в Приморском крае оставляет желать лучшего.

\section{Разрыв теории и практики: анализ барьеров, препятствующих успешной децентрализации государственной собственности на лесные ресурсы в Приморье}

После анализа состояния лесной отрасли, распределения и классификации прав собственности в Приморском крае была составлена вербальная модель децентрализации в регионе, которая представлена в виде диаграммы (рис. 1).

Как можно увидеть из рис. 1, наблюдается несоответствие желаемого и реального эффекта политики децентрализации. В Приморье выявлено довольно большое количество случаев нарушения договорных отношений, незаконной рубки деревьев, большое количество коррупционных скандалов, связанных с добычей древесины. На основании результатов исследовательской статьи А. Ковалева, А. Орлова, Е. Лашиной и Ю. Грищеновой «Состояние и перспективы использования лесных ресурсов Приморского края» можно отметить, что в регионе наблюдается истощение промышленно и технически значимых лесных ресурсов: «...резервов для лесных насаждений в регионе не осталось, практически весь эксплуатационный лесной фонд находится в аренде $-87.5 \%$ и пройден промышленными рубками» [14, с. 17]. Если говорить о воспроизводстве лесов, то авторы утверждают, что оно протекает вполне успешно: «Естественное возобновление основных лесообразующих пород обеспечивает необходимый минимум для восстановления насаждений заданного целевого состава» $[14$, с. 19], однако искусственное восстановление посредством посева и посадки лесных культур чрезмерно мало, вопреки прямому обязательству арендаторов проводить лесовосстановительные работы. По данным Фонда компенсационного лесовосстановления от 19.11.2020 г., из 1823,60 га общей площади участков только 391,70 га было восстановлено различными коммерческими компаниями [15]. 


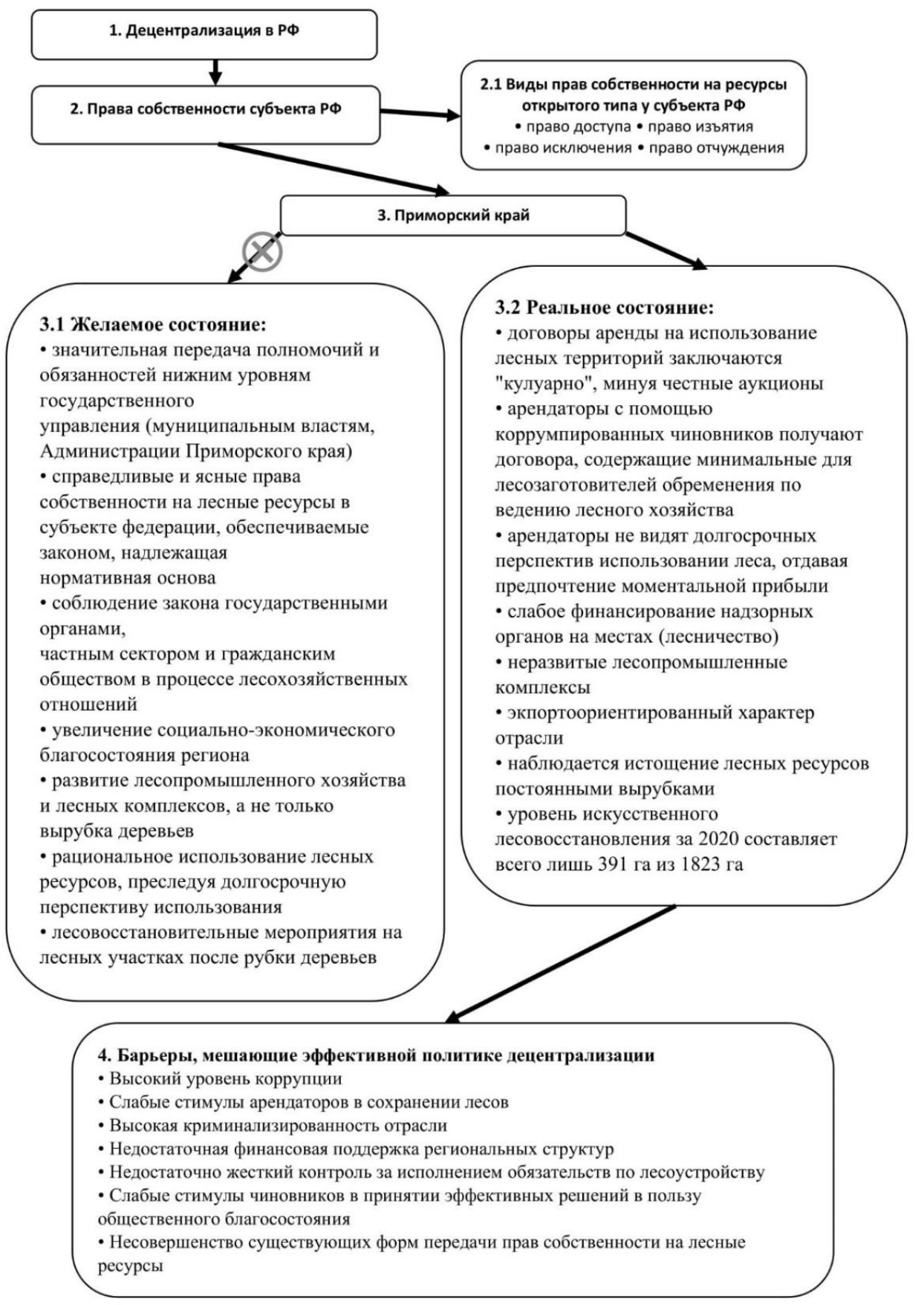

Puc. 1. Вербальная модель децентрализации государственной собственности на лесные ресурсы в Приморье. Источник: составлена авторами статьи

Rice. 1. Verbal model of decentralization of state ownership of forest resources in Primorye. Source: compiled by the authors of the article 
На 2019 г. объём средств, привлекаемых на реализацию целей государственной программы по развитию лесного хозяйства из федерального бюджета, составляет 373 562,50 тыс. рублей [16]. Этих средств недостаточно для полноценного и качественного функционирования органов надзора и управления в Приморском крае. Ухудшение данной ситуации с управлением лесными ресурсами может привести к снижению доходных поступлений, уничтожению лесных насаждений и ущербу природе в целом.

Далее будут подробно рассмотрены причины, снижающие эффективность децентрализации, и практические примеры. Проблема коррупции является большой преградой для эффективного функционирования децентрализации, в индексе восприятия коррупции, ежегодно публикуемом Transparency International, Россия находится на 137 месте из 180 [17]. В своём труде «Государство и экономические преобразования: к анализу условий эффективного государственного вмешательства», в котором рассматриваются два вида государственного устройства - «государства развития» и «хищнические государства», Д. Рюшемайер и П. Эванс отнесли Россию ко второму виду. Власть в «плохой стране» реализуется в деспотической или авторитарной форме, которая опирается не на законы и формальные правила, а на личные связи представителей самой власти - это чиновники, олигархи. Кроме этого, доходы извлекаются не в форме прибыли, а в форме ренты, которая зависит скорее от положения во властной структуре, а не от эффективности их деятельности. Представители власти ведут активную экономическую деятельность либо самостоятельно, либо через подставных лиц, используя современные рыночные механизмы, в первую очередь, для увеличения своего собственного заработка или для поддержания рейтинга популярности, чтобы дальше оставаться у власти, при этом практически ничего не делая для развития общественного благосостояния всей нации. В хищнических государствах власти начинают использовать административный ресурс в собственных целях, используя в том числе репрессивные формы насилия для того, чтобы и дальше осуществлять «рыночные отношения» для обслуживания собственных интересов [18].

Лесозаготовки являются одним из высокоприбыльных бизнесов в районе Приморья. Кандидат биологических наук и главный инженер «Центра природоохранных инициатив» Александр Олифиренко сообщает, что 1 кубометр сибирской сосны либо ели обходится в $3000-8000$ рублей. Стоимость дуба из этого региона может быть свыше 30 тыс. рублей за кубометр. А. Олифиренко считает, что только в этой части России заготовка древесины может приносить столь большую прибыль [19]. Вместе с высокой выгодой стремительно растёт и коррупция в данной сфере деятельности. Её показатель самый высокий в России. Криминальная составляющая в лесозаготовках начинается с «чёрных лесорубов», которые занимаются самовольной заготовкой дерева. В конце 2020 г. информировалось о деле, где работники департамента лесного хо- 
Кудлаев Д. В., Тищенко А. В. Неэффективность децентрализации государственной собственности в сфере лесопользования в Приморье: причины и возможные последствия

зяйства Приморского края подозревались в коррупционных действиях. В отношении подозреваемых было заведено уголовное дело по факту превышения должностных полномочий. Следствие считает, что сотрудники департамента заключили 5 соглашений на продление срока действия договоров с коммерческими организациями, обойдя торги. Итогом данных действий стало незаконное получение лесных участков для пользования этими компаниями. Стоит отметить, что эти участки находились в собственности государства. В итоге вырубка деревьев осуществлялась самовольно. Ущерб, причинённый лесному хозяйству, составил 909,5 млн руб. [20]. Эти неправомерные действия являются классической схемой заработка чиновников с нарушением законов. В данной схеме работники департамента лесного хозяйства нелегально сотрудничают с крупными арендаторами-лесорубами.

Если рассматривать время годом раньше, то можно увидеть, как чиновники и другие высокие должностные лица становились фигурантами крупных дел по факту коррупции. Во Владивостоке в 2019 г. бывший и. о. директора департамента лесного хозяйства Владимир Иванов был приговорён к 4 годам заключения и оштрафован на 35 млн руб. В. Иванов взял взятку в размере 550000 долларов за продление аренды лесного участка для рубки. Чиновник предложил нескольким компаниям за дополнительную плату (взятку) продлить осуществление лесной заготовительной деятельности путём продления аренды, 550000 долларов было получено им лично в июле 2016 г. во Владивостоке [21]. Итогом данных преступлений является всеобщая неэффективность распределения госсобственности среди бизнесменов. Самый большой ущерб лесам Приморья наносится компаниями, которые действуют формально, но на легальных основаниях. На сегодняшний день более $3 / 4$ леса в Приморье отданы в аренду для заготовки древесины. Стоит отметить, что большая доля договоров аренды заключалась в обход честных торгов, т. е. были приобретены кулуарно. В основном это произошло в то время, когда у власти стоял губернатор Сергей Михайлович Дарькин. Кроме того, непосредственное участие в этом принимали его ближайшие сподвижники, в частности руководитель Управления лесного хозяйства Приморского края Пётр Николаевич Диюк. В 2010 г. он сам рассказывал о том, как происходит воровство леса в Приморском крае. Запись была сделана скрытой камерой для документального фильма «Тёмный лес». За это он был на некоторое время отстранён от занимаемой должности, пока проводилась служебная проверка. Основанием для неё стали материалы, появившиеся в средствах массовой информации. Отстранение от должности было принято губернатором Дарькиным, которое основывалось на федеральном законе «О противодействии коррупции» и законе Приморского края «О государственной гражданской службе Приморского края» [22]. Г. Н. Жеребкин сообщает, что за 2000-2010 гг. в Приморском крае было «возбуждено 5792 уголовных дела по ст. 260 УК РФ, из которых только 1614 (27,9\%) направлено в суд, 300 (5,2\%) прекращены, 924 (16\%) 
находятся в стадии расследования и решения по ним ещё не приняты, остальные 2954 (51\%) - приостановлены» [23, с. 51]. Сейчас нелегальные вырубки проводятся организованно, высокопрофессионально, с применением современных технических средств. Данный вид нарушений серьёзно угрожает национальной безопасности в экологическом и экономическом отношении.

Департамент лесного хозяйства Приморского края в настоящее время перешёл в разряд министерства. Однако видно невооружённым глазом, что он не может справиться с возложенными на него обязанностями. В штате министерства большая нехватка специалистов, ведущих претензионную работу с пользователями леса, лесоустроителями либо чёрными лесорубами. Это связано, по мнению чиновников, с их малой зарплатой. П. Диюк в фильме «Тёмный лес» заявил о том, что за зарплату в 50 тыс. рублей не намерен тратить свои нервы и переживать из-за какого-то дерева, что во всём виновато воспитание, когда думаешь, где бы своровать [24]. Стоит отметить, что объёмы финансирования лесного хозяйства Приморского края из федерального и краевого бюджетов, вместе взятых, составляют около 450 млн рублей ежегодно [25]; в Хабаровском крае эти показатели выше в 2 раза, на Сахалине - в 1,6 раза, а на Камчатке, где заготовки и восстановление леса почти не проводятся, равны указанной сумме. Получается, что выделенных государством средств недостаточно даже для подсчёта объёмов леса, изъятого арендаторами в каком-либо году. Арендаторы этим и пользуются, занижая объёмы вырубленного леса в отчётах. А. А. Николайчук обращает своё внимание на важность прозрачного механизма учёта и маркировки заготовленной древесины, так как он обусловливает защиту «интересов не только собственника лесов - государства, но и всех участников лесных отношений» $[11$, с. 66]. Однако на данный момент нет единого метода учёта заготовленной древесины. Имеется также и проблема с размером предоставляемых под аренду лесных участков, так как «не существует минимальных ограничений, что приводит к ухудшению качества лесного фонда» [11, с. 67].

В России наблюдается ситуация «несовершенства системы институтов, которые определяют нормы, правила и процедуры вовлечения в хозяйственный оборот лесных ресурсов» $[11$, с. 62]. Это выражается в том, что при операциях с объектами лесного фонда учитываются интересы узких групп, а не общества в целом. Специфика же лесного фонда как экономической категории состоит в том, что всё, что произрастает на его территории, например, лес, деревья, растения, угодья является средствами производства и является частью лесохозяйственной деятельности. Леса, в свою очередь, являются рекреационным потенциалом, представляют естественную среду обитания человека и являются важной составляющей климата. По мнению автора, «сделки с объектами лесного фонда предполагают не просто физическую передачу товара из рук в руки, а именно переход прав собственности, полностью или частично, в другие руки» $[11$, с. 63$]$. 
Кудлаев Д. В., Тищенко А. В. Неэффективность децентрализации государственной собственности в сфере лесопользования в Приморье: причины и возможные последствия

В теории правильность сведений, которые предоставляются арендаторами в отчётах и актах, необходимо проверять участковым лесничим, которые являются главными представителями государства в лесу. Однако государство почти полностью освободило участковых от этого контроля. Они были лишены ряда полномочий и технологических возможностей находиться в лесу. Иногда участки лесничих могут располагаться в 100 километрах от их рабочих мест. Добраться туда можно только с помощью транспорта, а таковой им не предоставляется. Поэтому к месту заготовки древесины участковых отвозят сами же арендаторы [26]. Необходимо отметить, что сотрудникам лесничества Приморья, по информации Департамента лесного хозяйства ДФО, выплачивается самая малая заработная плата по сравнению с таковой в остальных регионах. Так, средняя зарплата лесничего в Приморском крае практически в 2 раза ниже средней заработной платы коллег из других административных единиц Дальнего Востока. На них возлагается обязанность предоставления достоверных сведений по договорам оборота древесины, в которых рыночная стоимость может исчисляться миллиардами рублей ежегодно. Соответственно, у всех работников появляется желание получить взятки. Лесничим, ввиду малого дохода, приходится идти на уступки и требования арендаторов за денежное вознаграждение. При этом лесная отрасль в Приморье становится криминальнее и беспорядочнее. Результатом неэффективности работы министерства является системный кризис лесного хозяйства в Приморье. Главными сложностями этого направления можно назвать: неправильную оценку стоимости лесоресурсов государством, коррупционные действия во время заключения и продления аренды и концессии, отсутствие госконтроля за проведением качественных хозяйственных лесомероприятий и правильностью отчётности организаций-арендаторов, преднамеренную ложную подачу данных во время проведения лесоустройства, формальное проведение госэкспертизы проектов освоения леса, недобросовестное проведение претензионных работ с нелегальными пользователями леса, ненадлежащее материальное и техническое обеспечение госорганов и уполномоченных в этой области [26].

Неэффективность децентрализации в Приморье может иметь крайне негативные последствия, приведёт в итоге к истощению лесных ресурсов, крайне низкому уровню их воспроизводства, нарушению экологического равновесия, естественной среды обитания человека, возможному изменению климата, а также к снижению доходных статей бюджета края и общему ухудшению условий проживания в регионе.

\section{Выводы}

По мнению ряда исследователей, последствия децентрализации государственной собственности в сфере лесопользования всё ещё недостаточно изучены, а результаты варьируются в разных странах. Однако многие из них отмечают и положительные черты этого процесса, в сравнении с политикой централизованного управления. 
Если говорить о России и Приморском крае, то остаётся неясным разграничение и контролирование прав собственности в лесопользовательских отношениях между арендаторами и субъектом региона, государством. В приведённых примерах наблюдается расхождение между тем, что написано в договорах купли-продажи, аренды, и тем, что видно в реальности: неисполнение арендаторами правил лесопользования, непонимание своих правовых границ, кумовство, непрозрачный учёт и вывоз древесины, нехватка финансовых возможностей для тщательного контроля за вырубкой лесов на местах и проведения лесовосстановительных работ. Коррупционные схемы между местной властью и бизнесом делают практически невозможным осуществление прозрачного отчёта о количестве вырубленных деревьев.

Нет сомнений в том, что децентрализация позволяет снять бремя управления с федеральной власти и упростить управление ресурсами на местах, однако данная политика требует эффективной работы институтов, прозрачной отчётности и добросовестной работы государственных органов, подчинения субъектов лесохозяйственных отношений законам и правилам. Одной из главных причин неэффективного использования лесных ресурсов в Приморском крае является неполноценная форма договорных отношений по лесопользованию на основе аренды, где арендатор, получая лесной участок, имеет лишь право изъятия (добыча древесины) и другие разрешённые виды деятельности, исключения и частичного отчуждения, но не право управления собственностью, что определяет его экстенсивное отношение к лесным ресурсам, нежелание развивать выделенные лесные участки. Причинами неэффективной децентрализации могут также являться отдалённость Приморского края от федерального центра, специфичность институциональных связей в России, тесная взаимосвязь между формальными и неформальными институтами, забюрократизированная управленческая и надзорная система, высокий уровень коррупции на местах, низкие стимулы приморских чиновников в принятии эффективных решений с точки зрения пользы для общества. Эти утверждения требуют дальнейшего исследования в будущих работах с целью более детального изучения проблем и поиска подходящих решений в условиях российской специфики управления лесными ресурсами.

\section{Список источников}

1. Валовой региональный продукт // Территориальный орган Федеральной службы государственной статистики по Приморскому краю. - URL: https://primstat.gks.ru/folder/27094 (дата обращения: 12.12.2020).

2. Шейнгауз, А. С. Лесной комплекс Дальнего Востока России: аналитический обзор / А. С. Шейнгауз. - Владивосток ; Хабаровск : ДВО РАН, 2005. - $160 \mathrm{c}$. 
Кудлаев Д. В., Тищенко А. В. Неэффективность децентрализации государственной собственности в сфере лесопользования в Приморье: причины и возможные последствия

3. Антонова, Н. Е. Трансформация лесного комплекса за годы российских реформ: дальневосточный срез. - DOI 10.14530/se.2017.3.083-106 // Пространственная экономика. - 2017. - № 3. - С. 83-106.

4. Schlager, E. Property-rights regimes and natural resources: A conceptual analysis / E. Schlager, E. Ostrom // Land Economics. -1992. - Vol. 68, №. 3. - P. 249-262.

5. Coleman, E. A. Property rights and forest commons / E. A. Coleman, S. S. Liebertz // Journal of Policy Analysis and Management. - Summer 2014. - Vol. 33, № 3. - P. 649-668.

6. Larson, A. The effects of forestry decentralization on access to livelihood assets / A. Larson, A. Pacheco, F. Toni // The Journal of Environment and Development. 2007. - Vol. 16, № 3. - P. 251-268.

7. Andersson, K. What motivates municipal governments? Uncovering the institutional incentives for municipal governance of forest resources in Bolivia // Journal of Environment \& Development. - 2003. - Vol. 12, № 1. - P. 5-27.

8. Forest governance in federal systems: an overview of experiences and implications for decentralization forest trends / H. Gregersen, A. Contreras-Hermosilla, A. White, L. Phillips. - Bogor : CIFOR, 2004. - VII, 80 p.

9. Forest ownership and management rights // Global Forest Resources Assessment of Russian Federation. - URL: https://fra-data.fao.org/RUS/fra2020/holderOf ManagementRights/ (дата обращения: 05.01.2021).

10. Лесной кодекс Российской Федерации : от 04.12.2006 № 200-Ф3 (ред. от 22.12.2020) // СПС «КонсультантПлюс». - URL: http://www.consultant.ru/documen t/cons.doc.LAW.64299/4936402833df1696d66ed00c4cf089c1444bad33/ (дата обращения: 05.01.2020).

11. Николайчук, А. А. Институциональный анализ прав собственности на лесные ресурсы в современной России // Молодой учёный. - 2010. - № 1. - С. 61-75.

12. Департамент лесного хозяйства Приморского края // Официальный сайт Администрации Приморского края. - URL: https://www.primorsky.ru/authorities/ex ecutive-agencies/departments/forestry/index_old.php?type=special (дата обращения: 05.01.2020).

13. Об утверждении типовых договоров аренды лесных участков : приказ Минприроды России от 30.07.2020 № 542 // СПС «КонсультантПлюс». - URL: http://www.consultant.ru/document/cons.doc.LAW.370142/ (дата обращения: 05.01.2020).

14. Состояние и перспективы использования лесных ресурсов Приморского края / А. П. Ковалев, А. М. Орлов, Е. В. Лашина, Ю. А. Грищенова // Сибирский лесной журнал. - 2019. - № 5. - С. 15-21.

15. Фонд компенсационного лесовосстановления Приморского края // Официальный сайт Администрации Приморского края. - URL: 
https://www.primorsky.ru/upload/medialibrary/6c3/6c3293ba96e2b68a76f08e89fe758ff3. xlsx (дата обращения: 04.01.2021).

16. Государственная программа Приморского Края «Развитие лесного хозяйства в Приморском крае на 2013-2020 годы» // Официальный сайт Администрации Приморского края. - URL: https:/www.primorsky.ru/aut horities/executive-agencies/departments/departament-gosprogramm/informatsiya-oproverkakh (дата обращения: 04.01.2021).

17. Corruption perceptions index 2019 // Transparency International. - URL: https://www.transparency.org/ru/publications/corruption-perceptions-index-2019 (дата обращения: 05.01.2021).

18. Рюшемайер, Д. Государство и экономические преобразования: к анализу условий эффективного государственного вмешательства / Д. Рюшемайер, П. Эванс // Экономическая социология. - 2011. - № 3. - С. 54-83.

19. Александр Олифиренко: как прекратить коррупцию в лесной отрасли края // Восток Медиа. - URL: https://vostokmedia.com/interview/28-022020/aleksandr-olifirenko-kak-prekratit-korruptsiyu-v-lesnoy-otrasli-kraya ～(дата обращения: 08.12.2020).

20. В Приморье выявили незаконную рубку леса на 900 миллионов рублей // РИА Новости. - URL: https://ria.ru/20201201/rubka-1587152430.html (дата обращения: 10.12.2020).

21. У экс-главы лесного департамента Приморья забрали трехэтажный особняк в пользу государства // PrimaMedia. - URL: https://primamedia.ru/news/ 951366/?from=37 (дата обращения: 10.12.2020).

22. Начальник управления лесным хозяйством Приморья Петр Диюк отстранен от должности // VL.RU. - URL: https://www.newsvl.ru/vlad/2010 /05/28/76722/ (дата обращения: 08.12.2020).

23. Жеребкин, Г. Н. Ответственность за незаконную рубку лесных насаждений Анализ нелегальных рубок на российском Дальнем Востоке и методика их расследования / Г. Н. Жеребкин. - Владивосток : WWF России, «Апельсин», 2011. - 136 с.

24. Глава приморского управления лесным хозяйством наговорил лишнего // Коммерсантъ. - URL: https://www.kommersant.ru/doc/1378787 (дата обращения: 08.12.2020).

25. Портал управления общественными финансами Приморского края. URL: https://ebudget.primorsky.ru/Menu/Page/341 (дата обращения: 07.12.2020).

26. Системный кризис лесного хозяйства Приморского края. Пути преодоления // Экодело. - URL: https://ecodelo.org/rossiyskaya_federaciya/dalnevo stochnyy_fo/primorskiy_kray/45119-sistemnyy_krizis_lesnogo_hozyaystva_ (дата обращения: 12.12.2020). 
Кудлаев Д. В., Тищенко А. В. Неэффективность децентрализации государственной собственности в сфере лесопользования в Приморье: причины и возможные последствия

\section{Информация об авторах}

Д. В. Кудлаев - студент-бакалавр, Школа экономики и менеджмента, Дальневосточный федеральный университет.

А. В. Тищенко - студент-бакалавр, Школа экономики и менеджмента, Дальневосточный федеральный университет.

\section{References}

1. Gross regional product. Territorial body of the Federal State Statistics Service in the Primorsky Territory. Available at: https://primstat.gks.ru/folder/27094 (accessed 12 December 2020). (In Russian).

2. Sheingauz A. S. Lesnoi kompleks Dal'nego Vostoka Rossii: analiticheskii obzor [Forest complex of the Far East of Russia: an analytical review]. Vladivostok; Khabarovsk: FEB RAS Publ., 2005. 160 p.

3. Antonova N. Ye. Transformatsiya lesnogo kompleksa za gody rossiiskikh reform: dal'nevostochnyi srez [Transformation of the forest complex during the years of Russian reforms: the Far East section]. Prostranstvennaya ekonomika, 2017, no. 3, pp. 83-106. DOI 10.14530/se.2017.3.083-106.

4. Schlager E., Ostrom E. Property-rights regimes and natural resources: A conceptual analysis. Land Economics, 1992, vol. 68, no. 3, pp. 249-262.

5. Coleman E. A., Liebertz S. S. Property rights and forest commons. Journal of Policy Analysis and Management, Summer 2014, vol. 33, no. 3, pp. 649-668.

6. Larson A., Pacheco A., Toni F. The effects of forestry decentralization on access to livelihood assets. The Journal of Environment and Development, 2007, vol. 16, no. 3, pp. 251-268.

7. Andersson K. What motivates municipal governments? Uncovering the institutional incentives for municipal governance of forest resources in Bolivia. Journal of Environment \& Development, 2003, vol. 12, no. 1, pp. 5-27.

8. Gregersen H., Contreras-Hermosilla A., White A., Phillips L. Forest governance in federal systems: an overview of experiences and implications for decentralization forest trends. Bogor: CIFOR, 2004. VII, $80 \mathrm{p}$.

9. Forest ownership and management rights. Global Forest Resources Assessment of Russian Federation. Available at: https://fra-data.fao.org/RUS/fra2020/holderOfMa nagementRights/ (accessed 01 May 2021).

10. Forest Code of the Russian Federation: dated 04.12.2006 No. 200-FZ (as amended on 22.12.2020). Available at: http://www.consultant.ru/document/cons.do c.LAW.64299/4936402833df1696d66ed00c4cf089c1444bad33/ (accessed 05 January 2020). (In Russian).

11. Nikolaychuk A. A. Institutsional'nyi analiz prav sobstvennosti na lesnye resursy v sovremennoi Rossii [Institutional analysis of property rights to forest resources in modern Russia]. Molodoi uchenyi, 2010, no. 1, pp. 61-75. 
12. Department of forestry of the Primorsky Territory. Official site of the Administration of the Primorsky Territory. Available at: https://www.primorsky.ru/autho rities/executive-agencies/departments/forestry/index_old.php?type=special (accessed 01 May 2020). (In Russian).

13. On approval of standard lease agreements for forest areas: order of the Ministry of Natural Resources of Russia dated July 30, 2020 No. 542. Available at: http://www.consultant.ru/document/cons.doc.LAW.370142/ (accessed 05 January 2020). (In Russian).

14. Kovalev A. P., Orlov A. M., Lashina E. V., Grishchenova Yu. A. Sostoyanie i perspektivy ispol'zovaniya lesnykh resursov Primorskogo kraya [Status and prospects of the use of forest resources of Primorsky Krai]. Sibirskii lesnoi zhurnal, 2019, no. 5, pp. 15-21.

15. Fund for compensatory reforestation of the Primorsky Territory. Official site of the Primorsky Territory Administration. Available at: https://www.primorsky.ru/upload/ medialibrary/6c3/6c3293ba96e2b68a76f08e89fe758ff3.xlsx (accessed 01 April 2021). (In Russian).

16. State program of the Primorsky Territory "Development of forestry in the Primorsky Territory for 2013-2020". Official site of the Primorsky Territory Administration. Available at: https://www.primorsky.ru/authorities/executive-agencies/departments/dep artament-gosprogramm/informatsiya-o-proverkakh (accessed 01 April 2021). (In Russian).

17. Corruption perceptions index 2019. Transparency International. Available at: https://www.transparency.org/ru/publications/corruption-perceptions-index-2019 (accessed 01 May 2021). (In Russian).

18. Rushemeyer D., Evans P. Gosudarstvo i ekonomicheskie preobrazovaniya: k analizu uslovii effektivnogo gosudarstvennogo vmeshatel'stva [State and economic transformations: to the analysis of conditions for effective government intervention]. Ekonomicheskaya sotsiologiya, 2011, no. 3, pp. 54-83.

19. Alexander Olifirenko: how to stop corruption in the timber industry of the region. Vostok Media. Available at: https://vostokmedia.com/interview/28-022020/aleksandr-olifirenko-kak-prekratit-korruptsiyu-v-lesnoy-otrasli-kraya (accessed 12 August 2020). (In Russian).

20. In Primorye, illegal logging for 900 million rubles was revealed. RIA Novosti. Available at: https://ria.ru/20201201/rubka-1587152430.html (accessed 10 December 2020). (In Russian).

21. A three-story mansion was taken away from the ex-head of the forestry department of Primorye in favor of the state. PrimaMedia. Available at: https://primamed ia.ru/news/951366/?from=37 accessed 10 December 2020). (In Russian).

22. The head of the forestry department of Primorye, Petr Diyuk, was removed from office. VL.RU. Available at: https://www.newsvl.ru/vlad/2010/05/28/76722/ (accessed 12 August 2020). (In Russian). 
23. Zherebkin G. N. Otvetstvennost' za nezakonnuyu rubku lesnykh nasazhdenii Analiz nelegal'nykh rubok na rossiiskom Dal'nem Vostoke i metodika ikh rassledovaniya [Responsibility for illegal logging of forest plantations Analysis of illegal logging in the Russian Far East and methods of their investigation]. Vladivostok: WWF Russia, "Apel'sin" Publ., 2011. 136 p.

24. The head of the Primorsky forestry department said too much. Kommersant. Available at: https://www.kommersant.ru/doc/1378787 (accessed 12 August 2020). (In Russian).

25. Portal for the management of public finances of the Primorsky Territory. Available at: https://ebudget.primorsky.ru/Menu/Page/341 (accessed 07 December 2020). (In Russian).

26. Systemic crisis of forestry in Primorsky Krai. Ways of overcoming. Ecodelo. Available at: https://ecodelo.org/rossiyskaya_federaciya/dalnevostochnyy_fo/primorsk iy_kray/45119-sistemnyy_krizis_lesnogo_hozyaystva (accessed: 12 December 2020). (In Russian).

\section{Information about the authors}

D. V. Kudlaev - Bachelor student, School of Economics and Management, Far Eastern Federal University.

A. V. Tishchenko - Bachelor student, School of Economics and Management, Far Eastern Federal University. 